\title{
$\widehat{A}$ Madridge \\ madridge Journal of Dermatology \& Research \\ Interconnecting Scientific World
}

Case Report

Open Access

\section{Cutaneous Plasmacytosis treated with Tocilizumab: A Case Report and Review of the Literature}

\author{
Timothy H Almazan and Jae Yeon Jung* \\ Division of Dermatology, City of Hope Comprehensive Cancer Center, USA
}

\section{Article Info}

*Corresponding author:
Jae Yeon Jung
Division of Dermatology
City of Hope Comprehensive Cancer
Center
1500 East Duarte Road
Duarte, CA 91010
USA
Tel: $626-256-4673$, ext: 65621
Fax: $626-301-8341$
E-mail: jjung@coh.org

Received: August 5, 2016

Accepted: August 31, 2016

Published: September 3, 2016

Citation: Almazan TH, Jung JY. Cutaneous Plasmacytosis treated with Tocilizumab: A Case Report and Review of the Literature. Madridge J Dermatol Res. 2016; 1(1): 1-7. doi: 10.18689/mjdr-1000101

Copyright: (c) 2016 The Author(s). This work is licensed under a Creative Commons Attribution 4.0 International License, which permits unrestricted use, distribution, and reproduction in any medium, provided the original work is properly cited.

Published by Madridge Publishers

\begin{abstract}
Objective: To review the current literature relevant to cutaneous plasmacytosis in both children and adults, with a focus on treatments documented as efficacious. Differing drug classes used to treat this disease and their respective outcomes will also be reviewed.
\end{abstract}

Data sources: A pubmed.org search was conducted using the search phrase "cutaneous plasmacytosis."

Data extraction:Information regarding clinical presentation, treatment, and pathophysiology of cutaneous plasmacytosis was specifically identified and reviewed.

Conclusions: Cutaneous and systemic plasmacytosis can affect both children and adults and presently lacks consensus statements on definitive treatment regimens. A continued consolidation of the little knowledge we have about this disease is needed, in order to uncover possible patterns of treatment efficacy, and to maintain awareness of this unusual disease in a dermatologist's differential diagnoses.

Keywords: Cutaneous Plasmacytosis; Tocilizumab; Lymphoplasmacytic Disorder; Myeloma cells; Plasma cells; Filipino woman.

\section{Introduction}

Cutaneous and systemic plasmacytosis is an extraordinarily rare, reactive lymphoplasmacytic disorder characterized by mature plasma cell proliferation in the skin or organs [1,2]. Unlike multiple myeloma, the plasma cells in plasmacytosis do not showcase atypia and are therefore considered benign. In the majority of cases, the expansion of plasma cells is polyclonal [3]. The vast majority of cases have been described in middle-aged individuals of Japanese decent. To our knowledge, only one other case has been described in a Filipino individual [4-6]. Here, we describe a second case of plasmacytosis in a Filipino woman.

\section{Case Report}

A 53-year-old Filipino woman presented to an outpatient clinic with numerous redbrown plaques on her face and trunk. The lesions were non-painful and had been present for approximately four years. She denied any constitutional symptoms including fevers, weight loss, or night sweats. An excisional biopsy of a chest wall lesion demonstrated mild, superficial perivascular plasma cells and anetoderma. A second biopsy of a similar lesion on the forehead revealed a possible diagnosis of cutaneous follicular lymphoma. Appropriately, the patient received an expedited bone marrow biopsy that resulted as negative for malignancy. A PET/CT scan uncovered FDG-avid 
bilateral cervical lymph node enlargement, along with minimally FDG-avid axillary, mediastinal, iliac, and inguinal adenopathy. An ultrasound-guided core biopsy of a cervical lymph node did not exhibit any evidence of lymphoma.

An excisional biopsy of a palpable groin lymph node disclosed reactive follicular hyperplasia, marked plasmacytosis, and Castleman-like features. The patient was subsequently started on thalidomide and prednisone to treat presumptive Castleman's disease. Despite therapy, she noted progression of her skin lesions, with additional hyperpigmented patches having evolved on her right breast and ankle.

Laboratory tests were significant for an elevated white blood cell count of $14.7 \mathrm{~K} / \mu \mathrm{L}$ and an increased monocyte differential of $16 \%$. The patient exhibited a normocytic anemia (hemoglobin of $11.1 \mathrm{~g} / \mathrm{dL}$ ) along with mild thrombocytosis (platelets $502 \mathrm{~K} / \mu \mathrm{L}$ ). Serum electrolytes were within normal limits. Total protein was elevated at $9.6 \mathrm{~g} / \mathrm{dL}$. Serum protein electrophoresis revealed an elevated gamma fraction without a monoclonal spike. No paraprotein was identified by immunofixation. Serum IgG was elevated at 2180 (normal range $700-1600 \mathrm{mg} / \mathrm{dL}$ ). Additionally, serum IL-6 was elevated at 19 (normal range $<5 \mathrm{pg} / \mathrm{mL}$ ).

The patient presented to our clinic for a second opinion, where a broad shave biopsy of her most recent lesion, located on the right breast, was taken. This showed a perivascular, polytypic plasma cell infiltration without lymphomatous involvementorCastleman-like changes. Immunohistochemical stains were negative for HHV-8. Plasma cells displayed both kappa and lambda restriction, indicating polyclonality.

With the clinical presentation of multiple truncal redbrown plaques, the overall findings seen on skin biopsy were consistent with a diagnosis of cutaneous plasmacytosis. As the patient had self-discontinued her thalidomide due to severe fatigue, a new treatment strategy was pursued using rituximab infusions (375 mg/m² every week for one month) and low dose prednisone.

The patient was treated with one month of rituximab at $375 \mathrm{mg} / \mathrm{m}^{2}$ (received 3 doses total) but did not showcase improvement. She was then attempted on tocilizumab $(8 \mathrm{mg} / \mathrm{kg})$ and received four monthly infusions. This resulted in improvement in the morphology of the patient's rash, particularly on the face and scalp, along with decreases in her ESR, CRP, and IL-6 levels. Rash on her back continues to persist. A repeat shave biopsy of a lesion on the patient's right upper back continued to show a perivascular, polytypic plasma cell infiltrate consistent with cutaneous plasmacytosis. The patient continues to receive follow up care to ensure no development of constitutional symptoms, or worsening of rash.

\section{Comment}

The condition now known as cutaneous and systemic plasmacytosis was first described in 1976 by Yashiro and colleagues [7-8] as a "kind of plasmacytosis." In 1980, Kitamura et al. [9] further refined the disease using the term "cutaneous plasmacytosis" [10]. Since then, it has been renamed as "cutaneous and systemic plasmacytosis $(\mathrm{C} / \mathrm{SP})$ " to reflect the high frequency of lymphoplasmacytic infiltration of extracutaneous sites [7]. In a minority of cases, C/SP is isolated to the skin alone. However, superficial lymphadenopathy often occurs in conjunction with skin findings in 58\% of patients [7]. Other extracutaneous sites of plasma cell infiltration may include the liver, spleen, kidney, and the lung. A case of lymphoid interstitial pneumonia and a case of proliferative glomerulonephritis have been reported in the literature $[1,7]$.

The extreme rarity of cutaneous and systemic plasmacytosis explains a lack of population-based studies; most information in the literature has been based primarily on case reports. The vast majority of C/SP has occurred in individuals of Japanese decent. However, cases have been reported in Chinese, Filipino, Korean, Hispanic, and Caucasian individuals [7]. A male to female ratio of 1:0.6, and a median age of presentation of 37 years has been reported $[7,11]$.

Cutaneous manifestations of the disease appear to be similar across all cases. Characteristically, patients present in middle age with reddish-brown to purplish infiltrated macules, plaques, and flat tumors located on the trunk [1]. The appearance of the rash is often insidious in nature. Other accompanying symptoms may include fever, lymphadenopathy, and hepatosplenomegally [1].

Serum gammaglobulins are often elevated, along with IL6 , a cytokine responsible for inducing terminal differentiation of $B$ cells into plasma cells [7]. Additionally, a normocytic anemia may be found.

Histopathology often reveals a dense, perivascular and perineural, mixed cell infiltrate with a predominance of mature plasma cells $[1,7]$. Infiltration occurs solely in the dermis and spares the epidermis. Polyclonality of the infiltrating plasma cells can be demonstrated with coexisting kappa and gammachain positive cells on immunohistochemical staining $[7,10]$. Furthermore, plasma cells do not showcase any degree of cellular atypia. Histology can mimic that of an extranodal, cutaneous, low-grade marginal-zone B cell lymphoma $[1,7]$.

In presentations where lymphadenopathy occurs, lymph node biopsy most closely resembles a reactive germinal center [1]. It is important to perform accurate immunophenotyping of the lymph node to distinguish cutaneous and systemic plasmacytosis from follicular lymphoma [1]. In cutaneous marginal B cell lymphoma, follicular colonization by either monoclonal or polyclonal plasma cells has been described [1]. It remains unclear whether there is a relationship or spectrum of disease between C/SP and lymphoma. There are reports of $\mathrm{C} / \mathrm{SP}$ patients developing malignant lymphomas, such as $\mathrm{T}$ cell lymphoma or non-Hodgkin's lymphoma. However, the relationship between C/SP and lymphoma currently remains unclear [1]. Transformation to plasma cell myeloma has not been reported [7].

The differential diagnosis for cutaneous and systemic plasmacytosis includes any disease entities resulting in plasma cell proliferation. These include chronic infection, collagen vascular disease, multiple myeloma, and cutaneous B cell lymphoma [7]. 


\begin{tabular}{|c|c|c|c|c|c|c|}
\hline Case & $\begin{array}{l}\text { Dem 0- } \\
\text { graphics }\end{array}$ & $\begin{array}{l}\text { Location of } \\
\text { lesions }\end{array}$ & Systemic findings & Notable labs & Treatments failed & Successful treatm ent r egim en \\
\hline $\begin{array}{l}\text { Yama- } \\
\text { moto et } \\
\text { al, } 1995\end{array}$ & $\begin{array}{l}47 \text { year old } \\
\text { man; } \\
\text { ethnicity } \\
\text { unspecified }\end{array}$ & $\begin{array}{l}\text { Cutaneous } \\
\text { nodules on } \\
\text { back }\end{array}$ & $\begin{array}{l}\text { Lymphadenopathy } \\
\text { absent }\end{array}$ & $\begin{array}{l}\text { Elevated IL-6 } \\
\text { Elevated IgG } \\
\text { Normal IgA } \\
\text { Normal IgM }\end{array}$ & $\begin{array}{l}\text { Topical PUVA } \\
\text { with cumulative } \\
\text { dosage of } 10.7 \\
\mathrm{~J} / \mathrm{cm} 2 \text { and } \\
\text { intralesional } \\
\text { interferon gamma } \\
\text { resulted in } \\
\text { incomplete } \\
\text { resolution of } \\
\text { lesions }\end{array}$ & $\begin{array}{l}\text { Intralesional triam cin olone, injected once a week, } \\
\text { duration unspecified, with a total cumulative dose of } \\
100 \mathrm{mg} \text {, induced complete clinical remission and } \\
\text { drastic decrease in serum IL - } 6 \text { levels }\end{array}$ \\
\hline $\begin{array}{l}\text { Kaneda } \\
\text { et al, } \\
1996\end{array}$ & $\begin{array}{l}51 \text { year old } \\
\text { man; } \\
\text { Japanese }\end{array}$ & $\begin{array}{l}\text { Trunk, } \\
\text { proximal } \\
\text { extremities, } \\
\text { scalp }\end{array}$ & LAD, HSM absent & $\begin{array}{l}\text { Elevated IgG } \\
\text { Normal IgM, } \\
\text { Elevated IgA }\end{array}$ & $\begin{array}{l}\text { Intermittent topical } \\
\text { steroids } \\
\text { (unspecified) }\end{array}$ & $\begin{array}{l}\text { Topical psor alen photoch emotherapy (PUVA). } \\
\text { Initial UVA dose } 0.6 \mathrm{~J} / \mathrm{cm}^{2} \text {. Performed } 3 \mathrm{x} / \text { week, then } \\
\text { increased to } 6 \mathrm{~J} / \mathrm{cm}^{2} \text { over two months. Then, patient } \\
\text { received once a week treatment for } 18 \text { additional } \\
\text { months. During first month, skin lesions of trunk and } \\
\text { extremities softened and flattened with slight residual } \\
\text { pigmentation }\end{array}$ \\
\hline $\begin{array}{l}\text { Carey et } \\
\text { al, } 1998\end{array}$ & $\begin{array}{l}78 \text { year old } \\
\text { man; } \\
\text { Caucasian }\end{array}$ & $\begin{array}{l}\text { Pink-red } \\
\text { papules on } \\
\text { chest, back, } \\
\text { shoulders, } \\
\text { arms, neck }\end{array}$ & $\begin{array}{l}\text { LAD, HSM } \\
\text { present }\end{array}$ & $\begin{array}{l}\text { Hemolytic } \\
\text { anemia, } \\
\text { thrombocyto- } \\
\text { penia, plasma- } \\
\text { cytosis in bone } \\
\text { marrow }\end{array}$ & None & $\begin{array}{l}2 \text { week regimen of prednisone } 60 \mathrm{mg} / \mathrm{day} \text { and IVIG } \\
\text { cleared cutaneous manifestations. Thrombocytopenia } \\
\text { improved only after both splenectomy and } \\
\text { cyclophosphamide administration }\end{array}$ \\
\hline $\begin{array}{l}\text { Hafner et } \\
\text { al, } 2006\end{array}$ & $\begin{array}{l}75 \text { year old } \\
\text { woman; } \\
\text { Caucasian }\end{array}$ & $\begin{array}{l}\text { Red-brown } \\
\text { macules on } \\
\text { face, cheeks, } \\
\text { nose }\end{array}$ & LAD absent & $\begin{array}{l}\text { Hypogamma- } \\
\text { globulinemia } \\
\text { Decreased IgG } \\
\text { Decreased IgM } \\
\text { Normal IgA }\end{array}$ & None & $\begin{array}{l}\text { Topical pim ecrolimus } 1 \% \text { ointm ent twice a day for } \\
\text { facial lesions. After } 3 \text { weeks, rash had nearly } \\
\text { resolved. Maintenance with } 1 \% \text { ointm ent daily for } 2 \\
\text { months resulted in sustained remission }\end{array}$ \\
\hline $\begin{array}{l}\text { Haque et } \\
\text { al, } 2011\end{array}$ & $\begin{array}{l}67 \text { year old } \\
\text { man; } \\
\text { Caucasian }\end{array}$ & $\begin{array}{l}\text { Reddish- } \\
\text { brown } \\
\text { macules, } \\
\text { patches, and } \\
\text { plaques over } \\
\text { upper and } \\
\text { lower trunk }\end{array}$ & LAD present & $\begin{array}{l}\text { Iron deficiency } \\
\text { anemia, elevated } \\
\text { creatinine, } \\
\text { elevated total } \\
\text { protein, elevated } \\
\text { IgG, IgA, and } \\
\text { IgM, elevated } \\
\text { CRP, elevated } \\
\text { IL }-6\end{array}$ & $\begin{array}{l}\text { Prednisone } \\
60 \mathrm{mg} / \text { day led to } \\
\text { partial resolution of } \\
\text { skin lesions }\end{array}$ & $\begin{array}{l}8 \text { cycles of multi-agent chemotherapy } \\
\text { (cyclophosphamide, doxorubicin, vinblastine, and } \\
\text { prednisone) administered due to plasma cell } \\
\text { infiltration of the kidneys. Near complete clearing of } \\
\text { skin lesions resulted, along with post-inflammatory } \\
\text { hyperpigmentation }\end{array}$ \\
\hline $\begin{array}{l}\text { Tzung et } \\
\text { al, } 2013\end{array}$ & $\begin{array}{l}72 \text { year old } \\
\text { man; } \\
\text { Chinese }\end{array}$ & $\begin{array}{l}\text { Brown, } \\
\text { in durated } \\
\text { plaques on } \\
\text { face, upper } \\
\text { chest, back }\end{array}$ & LAD, HSM absent & $\begin{array}{l}\text { Elevated IgG } \\
\text { and evidence of } \\
\text { polyclonal } \\
\text { hypergamma- } \\
\text { globulinemia } \\
\text { Normal IL-6 } \\
\text { levels }\end{array}$ & $\begin{array}{l}\text { Psoralen plus UVA } \\
\text { (PUVA) treatment } \\
\text { did not improve } \\
\text { skin lesions after } \\
\text { after cumulative } \\
\text { dosage of } 27 . .2 \\
\mathrm{~J} / \mathrm{cm} 2 \text {. } \\
\text { Intralesional } \\
\text { triamcinolone } \\
\text { injection was used } \\
\text { on one of the back } \\
\text { lesions without } \\
\text { improvement }\end{array}$ & $\begin{array}{l}\text { Topical 5-aminolaevulinic acid (5-ALA) } \\
\text { photodynamic therapy with long-pulsed ruby laser } \\
\text { monthly lead to decreased skin infiltration of rash } \\
\text { after } 3^{\text {rd }} \text { irradiation. Length of treatment not stated }\end{array}$ \\
\hline $\begin{array}{l}\text { Oka et } \\
\text { al, } 2013\end{array}$ & $\begin{array}{l}88 \text { year old } \\
\text { woman; } \\
\text { Japanese }\end{array}$ & $\begin{array}{l}\text { Erythema- } \\
\text { tous plaques } \\
\text { on face, neck } \\
\text { extremities, } \\
\text { trunk }\end{array}$ & LAD present & $\begin{array}{l}\text { Anemia } \\
\text { Elevated IgG } \\
\text { Elevated IgA }\end{array}$ & $\begin{array}{l}\text { Topical steroids } \\
\text { (unspecified) }\end{array}$ & $\begin{array}{l}\text { Oral prednisone } 20 \mathrm{mg} / \mathrm{daily}(0.4 \mathrm{mg} / \mathrm{kg} / \text { day). Face, } \\
\text { neck, extremity lesions improved within } 1-3 \text { weeks. } \\
\text { Trunk macules eradiated within } 3 \text { months, leaving } \\
\text { only slight residual pigmentation }\end{array}$ \\
\hline $\begin{array}{l}\text { Jia et al, } \\
2013\end{array}$ & $\begin{array}{l}51 \text { year old } \\
\text { man; } \\
\text { ethnicity } \\
\text { unspecified }\end{array}$ & $\begin{array}{l}\text { Infiltrative } \\
\text { tubercles/ } \\
\text { plaques on } \\
\text { right leg, } \\
\text { perioral and } \\
\text { abdomen } \\
\text { regions }\end{array}$ & LAD present & $\begin{array}{l}\text { Elevated IgG } \\
\text { Normal IgA } \\
\text { Normal IgM }\end{array}$ & None & $\begin{array}{l}\text { Intramuscular injections of interferon and } 1 \\
\text { million } U / d a y \times 9 \text { months, oral triam cinolone } \\
16 \mathrm{mg} / \text { day } \times 1 \text { months, oral acitretin capsules } \\
\text { (unspecified dose) } 33 \text { months. Disappearance of } 1 \mathrm{eg}, \\
\text { perioral, and abdominal eryth ema/tubercles }\end{array}$ \\
\hline
\end{tabular}

Table 1: Reported effective treatment regimens attempted for patients with cutaneous plasmacytosis. LAD: lymphadenopathy, HSM: hepatosplenomegally. 


\begin{tabular}{|c|c|c|c|}
\hline \multicolumn{4}{|c|}{ Antibiotics } \\
\hline $39 \mathrm{M}$ & $\begin{array}{l}\text { doxycycline } \mathrm{x} 1 \text { month (combined with } 3 \text { weeks of } \\
\text { dobetasol ointment) }\end{array}$ & no improvement in lesions & Brezinski et al \\
\hline \multicolumn{4}{|c|}{ Antin eoplastics / chem otherapy } \\
\hline $39 \mathrm{M}$ & bortezomib $1.3 \mathrm{mg} / \mathrm{m} 2$ twice a week $\mathrm{x} 2$ cycles & partial regression of lesions & Brezinski et al \\
\hline $49 \mathrm{M}$ & $\begin{array}{l}\text { cyclophosphamide, doxorubicin, vincristine, and } \\
\text { prednisone chemotherapy }\end{array}$ & partial, transient resolution of lesions & Amin et al \\
\hline $40 \mathrm{M}$ & chlorambucil $6 \mathrm{mg}$ PO qday $\times 5$ months & no significant improvement & Lopez-Estebaranz et al \\
\hline $49 \mathrm{M}$ & 4-week course of anti-CD20 antibody (Rituximab) & no clinical response & Amin et al \\
\hline \multicolumn{4}{|c|}{ Oral steroids } \\
\hline $51 \mathrm{M}$ & tapered course of prednisone, starting with $40 \mathrm{mg} / \mathrm{day}$ & $\begin{array}{l}\text { flattening of the lesions noted; skin biopsy showed little change in } \\
\text { cellular infiltrate }\end{array}$ & Haque et al \\
\hline $49 \mathrm{M}$ & prednisone $1 \mathrm{mg} / \mathrm{kg}$ & $\begin{array}{l}\text { reduction in pulmonary symptoms and adenopathy but no change } \\
\text { in the skin lesions }\end{array}$ & Amin et al \\
\hline $22 \mathrm{M}, 62 \mathrm{~F}$ & predni solone $30 \mathrm{mg}$ daily $\mathrm{x} 8$ weeks & no improvement & Watanabe et al \\
\hline $54 \mathrm{M}, 55 \mathrm{M}$ & prednisolone $0.25 \mathrm{mg} / \mathrm{kg}$ & $\begin{array}{l}\text { incomplete reduction in size of the skin lesions was observed; } \\
\text { diminution in size of lymph nodes and improvement of systemic } \\
\text { symptoms noted }\end{array}$ & $\begin{array}{l}\text { Miyagawa-Hayashino } \\
\text { et al }\end{array}$ \\
\hline \multicolumn{4}{|c|}{ Topical therapy } \\
\hline $61 \mathrm{M}$ & tacrolimus ointment (applied to facial lesions) & reduction of facial erythema and induration & $\begin{array}{l}\text { Miyagawa-Hayashino } \\
\text { et al }\end{array}$ \\
\hline $66 \mathrm{~F}$ & $\begin{array}{l}\text { initially treated with topical corticosteroids, then trialed } \\
\text { on topical cal cineurin inhibitors: tacrolimus ointment } \\
0.1 \% \text { and pimecrolimus cream } 1 \%\end{array}$ & only a slight improvement was observed & Gonzal es-L opez et al \\
\hline $49 \mathrm{M}$ & $\begin{array}{l}\text { tacr olimus } 0.1 \% \text { ointment topical therapy twice daily for } \\
\text { the facial skin lesions }\end{array}$ & $\begin{array}{l}\text { regression of red-brownish plaques on face; lesions resumed } \\
\text { original appear ance } 3 \text { weeks after discontinuing the therapy }\end{array}$ & Ma et al \\
\hline $55 \mathrm{M}$ & tacrolimus ointment twice a day & $\begin{array}{l}\text { reduction of erythema and induration of the facial lesions after } 3 \\
\text { months }\end{array}$ & Miura et al \\
\hline \multicolumn{4}{|c|}{ Isotretinoin } \\
\hline $67 \mathrm{M}$ & $\begin{array}{l}\text { isotretinoin } 60 \mathrm{mg} / \text { day for } 2 \text { months administered for } \\
\text { residual skin lesions (after multi-agent chemo given) }\end{array}$ & no apparent benefit & Haque et al \\
\hline \multicolumn{4}{|c|}{ Intralesional steroids } \\
\hline $35 \mathrm{M}$ & unspecified intralesional steroid and topical tacrolimus & persistence of skin lesions & Chantachaeng et al \\
\hline $33 \mathrm{~F}$ & intralesional triamcinolone injections to a few lesions & afforded temporary relief of itch and flattening of lesions & Lee et al \\
\hline \multicolumn{4}{|c|}{ Multi-class, combination therapy } \\
\hline $45 \mathrm{M}$ & $\begin{array}{l}\text { prednisone } 20 \mathrm{mg} / \text { day, tranilast } 300 \mathrm{mg} / \text { day, thalidomide } \\
75 \mathrm{mg} / \text { day; also received tacrolimus } 0.1 \% \text { ointment } \\
\text { topical therapy twice daily }\end{array}$ & no remission observed & Chen, Y. et al \\
\hline $43 \mathrm{M}$ & $\begin{array}{l}\text { prednisolone } 30 \mathrm{mg} / \text { day, thalidomide } 150 \mathrm{mg} / \mathrm{day} \text {, and } \\
\text { tacrolimus } 0.1 \% \text { topical ointment twice daily }\end{array}$ & $\begin{array}{l}\text { regression of plaques after } 2 \text { months of treatment; lesions resumed } \\
\text { original appear ance after discontinuing therapy }\end{array}$ & Chen, $H$. et al \\
\hline $33 \mathrm{~F}$ & $\begin{array}{l}\text { potent topical corticosteroids (unspecified) and } 8 \text { months } \\
\text { of photother apy with narrow band ultraviolet light }\end{array}$ & no improvement and the lesions continued to darken & Lee et al \\
\hline $54 \mathrm{M}$ & $\begin{array}{l}\text { oral prednisolone ( } 30 \mathrm{mg} / \text { day) and cycl ophosphamide } \\
(100 \mathrm{mg} / \text { day })\end{array}$ & no significant improvement & Kodama et al \\
\hline \multicolumn{4}{|c|}{ Multi-class, combination therapy involving photochem oth erapy } \\
\hline $51 \mathrm{M}$ & $\begin{array}{l}3 \text { months of methox salen UV-A photochemotherapy } \\
\text { al one and then } 1 \text { month of interferon alfa ( } 3 \text { million units) } \\
3 \text { times weekly added to the PUVA regimen }\end{array}$ & no improvement & Haque et al \\
\hline $27 \mathrm{M}$ & PUVA and corticosteroids (unspecified) & no significant improvement & Shimzu et al \\
\hline
\end{tabular}

Table 2: Partially successful, or unsuccessful treatment regimens and drug classes reported in the literature.

Due to the characteristic elevation of IL-6 seen in cutaneous and systemic plasmacytosis, some clinicians hypothesize that the disease is a variant of multicentric Castleman's disease (MCD). IL-6 induces B-cell proliferation and differentiation into plasma cells, immunoglobulin secretion, and angiogenesis [10]. IL-6 overproduction has been considered a key driving factor in the pathogenesis 
of MCD [10]. Castleman's disease was first reported in 1956 by Benjamin Castleman, who described a lymphoproliferative disorder in patients with mediastinal lymphadenopathy [10]. Multicentric Castleman's disease (MCD) is associated with lymphadenopathy, hyperproteinemia, hypergammaglobulinemia, increased erythrocyte sedimentation rate, and systemic symptoms such as fever, weight loss, and anemia. The plasma cell variant of cutaneous MCD results in skin histology that is similar to that of cutaneous and systemic plasmacytosis [10]. Interestingly, IL-6 elevation is not seen in all cases of C/SP, as some case reports reveal patients with normal levels despite clinical disease [12]. In a case where IL- 6 was elevated at the time of disease presentation, treatment success was associated with a subsequent decrease in IL-6 levels [13].

Compared with multicentric Castleman's disease, most patients diagnosed with $\mathrm{C} / \mathrm{SP}$ have a relatively favorable clinical course and prognosis [10]. However, a few cases of C/SP have followed an aggressive course resulting in fatal outcome [7]. Causes of death reported in the literature include leukemia, lymphoid interstitial pneumonia, and renal failure [7]. A few malignancies arising in patients with $\mathrm{C} / \mathrm{SP}$ include $\mathrm{T}$-cell lymphoma, and solid tumors such as lung, anal, and gastric cancer [10]. Uhara and colleagues suggest that a serum immunoglobulin level greater than $5000 \mathrm{mg} / \mathrm{dL}$ and plasma cell counts greater than $6.9 \%$ in the bone marrow are associated with more severe disease [14]. Though there are no consensus statements on follow-up, patients with a diagnosis of cutaneous or systemic plasmacytosis should be monitored longitudinally to assess for the possibility of malignant transformation [7].

The cause of cutaneous and systemic plasmacytosis is not known. A widespread hypothesis states that C/SP is a variant of reactive plasmacytic disorders [7]. Most cases have no detectible inciting cause. One case of C/SP noted the presence of skin lesions in a prior area of leg trauma [2]. The geographic distribution of C/SP cases with the majority occurring in Japan lead to the speculation that a primary infectious or environmental cause is responsible [7].

There is no uniform, conclusive method for the treatment of cutaneous and systemic plasmacytosis [2]. Topical and systemic steroids, radiation, topical tacrolimus, pimecrolimus, antibiotics, systemic chemotherapy, and anti-CD20 antibody therapy have been tried in C/SP with inconsistent results $[10,11,14,15]$. Only a handful of case reports describe significant improvement or remission in the treatment of C/ SP. Table 1 represents cases published in the literature that have demonstrated notable treatment success.

Though rituximab, either alone or combined with cytotoxic agents, can induce sustained remissions in patients with multicentric Castleman's disease [16-18], there has been little experience with this drug in the treatment of cutaneous and systemic plasmacytosis. The interleukin- 6 receptor (IL-6R) has been a viable target in multicentric Castleman's disease, where antagonism by the monoclonal antibody siltuximab, has shown favorable responses in a phase 2 study $[19,20]$. The safety and efficacy of tocilizumab was demonstrated in 28 symptomatic, HIV-negative patients with plasma cell type multicentric
Castleman's disease. Patients were treated with tocilizumab $8 \mathrm{mg} / \mathrm{kg}$ every two weeks for 16 weeks and noted that the drug alleviated lymphadenopathy and inflammatory markers. An additional subset of patients who had received oral corticosteroids prior to study entry were able to have their corticosteroid dose reduced without disease flare [21].

As both multicentric Castleman's disease and C/SP are associated with increased serum levels of IL-6, IL-6 antagonists may be an untapped resource for potential treatments for cutaneous and systemic plasmacytosis. Bortezomib, a $26 \mathrm{~S}$ proteasome inhibitor used in the treatment of multiple myeloma and mantle cell lymphoma, is known to decrease the production of IL-6 via NFKB $[19,22]$. Brezinski and colleagues attempted treatment of antibiotic-refractory cutaneous plasmacytosis with twice weekly bortezomib. After two cycles, no new lesions developed, and persistent plaques had evidence of regression [3]. Ahmad et al describe a case of cutaneous Castleman's disease treated with a chimeric murine anti-human IL-6 antibody [23].

\section{Pediatric Cases}

A total of seven cases of cutaneous plasmacytosis in children have been described in the literature thus far. Interestingly, every case involved isolated skin lesions without the characteristic systemic symptoms seen in adults. Each pediatric case revealed uniform skin biopsy results, consisting of a dense, polyclonal plasma cell infiltrate in the superficial and mid dermis. A substantial fraction of pediatric cases involved lesions located on the extremities; this differs from the truncal distribution of lesions commonly seen in adults. The lack of systemic symptoms accompanying the skin lesions has prompted some authors to suggest that cutaneous plasmacytosis in children may be a completely separate entity from plasmacytosis in adults [24]. Others suggest that pediatric cutaneous plasmacytosis may be an example of a benign, cutaneous infiltrate of immune cells akin to entities such as incontinentia pigmenti, erythema toxicum neonatorum, Ofuji syndrome and eosinophilic pustular folliculitis $[25,26]$.

\section{Conclusion}

Less than one hundred cases of cutaneous and systemic plasmacytosis have been documented in the literature. The lack of formal guidelines regarding treatment of this exceedingly rare disease necessitates a continued analysis of attempted treatments, whether successful or unsuccessful, in order to uncover possible patterns of efficacy. To our knowledge, the use of tocilizumab in the treatment of cutaneous plasmacytosis has not been documented, however its efficacy in multicentric Castleman's disease, a condition with many similarities to C/SP, is well known. Our patient did showcase symptomatic improvement after tocilizumab, with improved appearance of her rash, and notable decrease in her inflammatory markers. Interestingly, such improvements were not noted after three doses of rituximab. Due to the rarity of this disease, no randomized control trials exist comparing the efficacy of tocilizumab versus rituximab in the treatment of cutaneous plasmacytosis. 


\begin{tabular}{|c|c|c|c|c|c|c|c|}
\hline Case & Demographics & $\begin{array}{l}\text { Distribution of } \\
\text { lesions }\end{array}$ & $\begin{array}{c}\text { Years } \\
\text { lesions } \\
\text { present }\end{array}$ & $\begin{array}{l}\text { Systemic } \\
\text { findings }\end{array}$ & Notable labs & $\begin{array}{l}\text { Treatment(s) } \\
\text { attempted }\end{array}$ & Outcome \\
\hline $\begin{array}{l}\text { Shiba } \\
\text { et al }\end{array}$ & $\begin{array}{l}16 \mathrm{~F} \text {, Japanese; no } \\
\text { past medical } \\
\text { history }\end{array}$ & $\begin{array}{l}2-5 \mathrm{~mm} \text { reddish } \\
\text { nodules on } \\
\text { dorsum of left } \\
\text { hand }\end{array}$ & 1 & None & $\begin{array}{l}\text { ANA 1:2560. } \\
\text { Decreased to } \\
1: 160 \text { after } \\
\text { excision }\end{array}$ & Excision & $\begin{array}{l}\text { No recurrence in } 6 \mathrm{mo} \\
\text { follow-up period }\end{array}$ \\
\hline $\begin{array}{l}\text { Arico et } \\
\text { al }\end{array}$ & $\begin{array}{l}7 \mathrm{~F} \text {, Caucasian; } \\
\text { history of type } 1 \\
\text { diabetes }\end{array}$ & $\begin{array}{l}\text { Red-brown } \\
\text { papules and } \\
\text { nodules with one } \\
\text { large solitary } \\
\text { plaque } 10 \mathrm{~cm} \text { in } \\
\text { diameter in } \\
\text { axillary / scapular } \\
\text { region }\end{array}$ & 4 & None & None & $\begin{array}{l}\text { Treated } \\
\text { intermittently with } \\
\text { topical } \\
\text { corticosteroids }\end{array}$ & $\begin{array}{l}\text { No improvement with } \\
\text { corticosteroids; no } \\
\text { definitive treatment } \\
\text { described }\end{array}$ \\
\hline \multirow[t]{2}{*}{$\begin{array}{l}\text { Gillian } \\
\text { et al }\end{array}$} & $\begin{array}{l}\text { 15F, Caucasian; } \\
\text { history of varicella } \\
\text { and molluscum }\end{array}$ & $\begin{array}{l}\text { Violaceous plaque } \\
\text { of left anterior } \\
\text { tibia } 4.5 \times 1.9 \mathrm{~cm} \\
\text { in diameter }\end{array}$ & 11 & None & $\begin{array}{l}\text { ANA } 1: 80 \\
\text { (speckled), IgE } \\
\text { level elevated at } \\
0.277 \mathrm{U} / \mu \mathrm{L} \\
\text { (normal value, } \\
<0.115 \mathrm{U} / \mu \mathrm{L} \text { ) }\end{array}$ & $\begin{array}{l}\text { Treated with } \\
\text { pulsed-dye laser } \\
\text { for cosmetic } \\
\text { purposes }\end{array}$ & $\begin{array}{l}\text { Fading of the violaceous } \\
\text { color }\end{array}$ \\
\hline & $\begin{array}{l}7 \mathrm{M} \text {, Caucasian; no } \\
\text { past medical } \\
\text { history }\end{array}$ & $\begin{array}{l}\text { Scaling, } \\
\text { violaceous } \\
\text { papulonodules on } \\
\text { the leg }\end{array}$ & 2 & None & $\begin{array}{l}\text { Slightly } \\
\text { depressed C4 } \\
\text { level with } \\
\text { normal C3 }\end{array}$ & Not described & Not described \\
\hline $\begin{array}{l}\text { Ahn et } \\
\text { al }\end{array}$ & $\begin{array}{l}7 \mathrm{~F}, \text { Korean; no past } \\
\text { medical history }\end{array}$ & $\begin{array}{l}\text { Erythematous } \\
\text { scaly plaque on } \mathrm{R} \\
\text { buttock, } 2 \times 3 \mathrm{~cm}\end{array}$ & 5 & None & $\begin{array}{l}\text { Mildly elevated } \\
\text { immunoglo- } \\
\text { bulin E level of } \\
221 \mathrm{IU} / \mathrm{mL}\end{array}$ & $\begin{array}{l}\text { Topical } \\
\text { methylpredniso- } \\
\text { lone acetate and } \\
\text { topical calcitriol } \\
\text { without significant } \\
\text { improvement; } \\
\text { topical tacrolimus } \\
\text { ointment } \\
\text { ineffective }\end{array}$ & $\begin{array}{l}\text { Oral prednisolone and } \\
\text { intralesional triamcinolone } \\
\text { injections, with topical } \\
\text { methyl-prednisolone } \\
\text { resulted decreased size and } \\
\text { induration of lesion. Lesion } \\
\text { reappeared } 3 \text { mo after } \\
\text { completion of regimen; } \\
\text { lesion ultimately was } \\
\text { excised }\end{array}$ \\
\hline $\begin{array}{l}\text { Song et } \\
\text { al }\end{array}$ & $\begin{array}{l}\text { 1F, ethnicity not } \\
\text { specified; no past } \\
\text { medical history }\end{array}$ & $\begin{array}{l}\text { Solitary } \\
\text { ery thematous } \\
\text { plaque on } \mathrm{R} \text { calf }\end{array}$ & $\begin{array}{l}1 \\
\text { (present } \\
\text { at birth) }\end{array}$ & None & None & $\begin{array}{l}\text { Methylpred- } \\
\text { nisolone aceponate } \\
\text { cream }\end{array}$ & $\begin{array}{l}\text { Mild improvement without } \\
\text { complete recovery }\end{array}$ \\
\hline On et al & $\begin{array}{l}\text { 3F, ethnicity not } \\
\text { specified; no past } \\
\text { medical history }\end{array}$ & $\begin{array}{l}1 \times 3 \mathrm{~cm} \text { solitary } \\
\text { ery thematous } \\
\text { plaque on right } \\
\text { knee }\end{array}$ & 1 & None & None & $\begin{array}{l}\text { Topical } \\
\text { corticosteroids } \\
(0.3 \% \text { diflu- } \\
\text { cortolone valerate } \\
\text { ointment) }\end{array}$ & $\begin{array}{l}\text { After } 1 \text { month, lesion } \\
\text { decreased in size; } \\
\text { indurated ery thema mostly } \\
\text { disappeared }\end{array}$ \\
\hline
\end{tabular}

Table 3: Pediatric cases of cutaneous plasmacytosis.

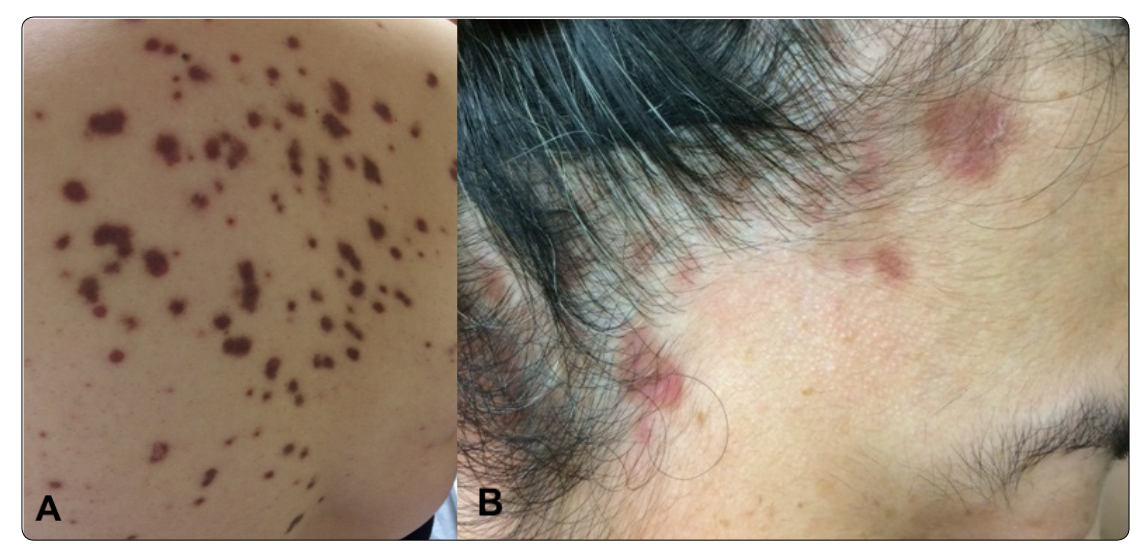

Figure 1: Clinical appearance of the patient's skin lesions upon presentation. Red-purple plaques on the trunk (A) and face (B). 
Our observations suggest that tocilizumab be considered as a potential efficacious regimen in the treatment of cutaneous plasmacytosis associated with elevated IL-6 levels.

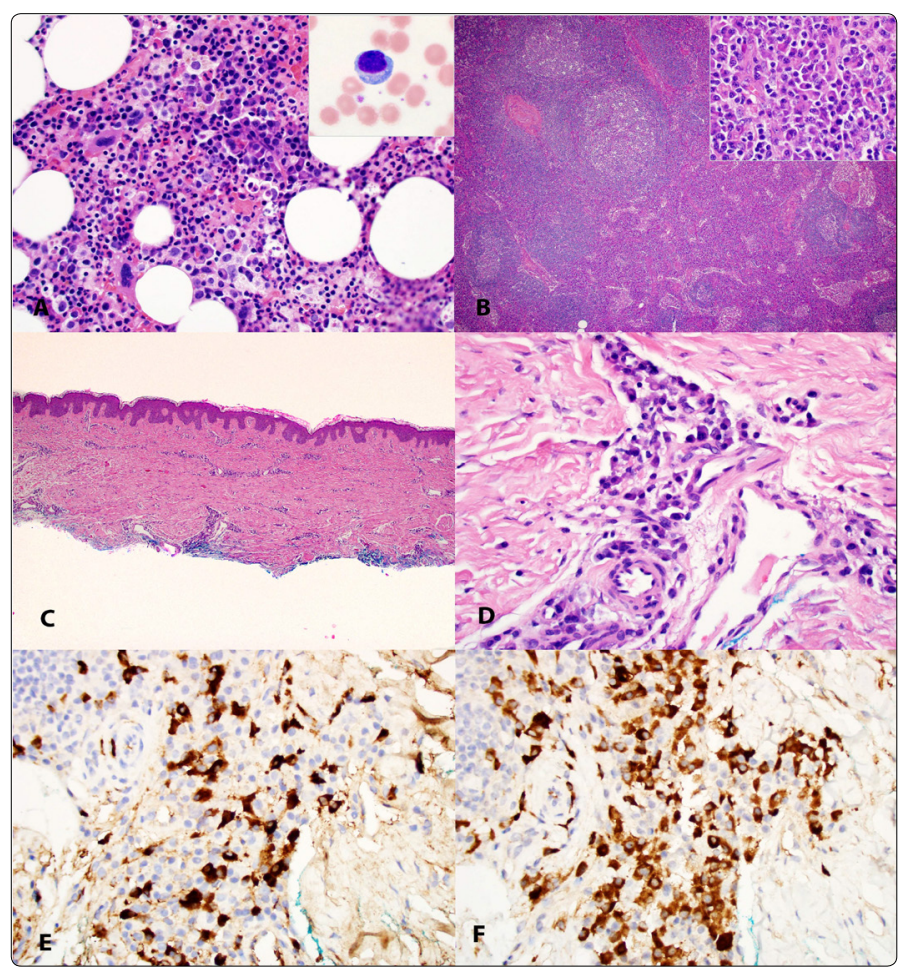

Figure 2: Cutaneous plasmacytosis. The bone marrow (A) showing scattered collections of mature plasma cells. There are circulating plasmacytoid lymphocytes (inset) in the peripheral blood. The lymph node (B) shows extensive polytypic plasmacytosis within the interfollicular areas (high power, inset). The skin biopsy (C) shows mostly a dermal plasmacytosis that is perivascular (D) with no epidermotropism. The kappa (E) and lambda (F) immunohistochemistry shows polytypic plasma cells.

\section{References}

1. Honda $R$, Cerroni L, Tanikawa A, Ebihara $T$, Amagai M, Ishiko A. Cutaneous plasmacytosis: report of 6 cases with or without systemic involvement. J Am Acad Dermatol. 2013; 68(6):978-985. doi: 10.1016/j. jaad.2012.11.031

2. Xia JX, Li FQ, Zhang M, et al. A case of cutaneous plasmacytosis. Exp Ther Med. 2013; 5(4):1211-1213. doi: 10.3892/etm.2013.928

3. Brezinski EA, Fung MA, Fazel N. Cutaneous plasmacytosis with perineural involvement. Case Rep Dermatol Med. 2014;(2014):840845.

4. Jayaraman AG, Cesca C, Kohler S. Cutaneous plasmacytosis: A report of five cases with immunohistochemical evaluation for HHV-8 expression. Am J Dermatopathol.2006;28(2):93-8. doi:10.1097/01.dad.0000181107.08791.87

5. Chantachaeng W, Chularojanamontri L. Cutaneous plasmacytosis: a case report and review of pulmonary findings. Dermatol Reports. 2011; 3(3):e39. doi: 10.4081/dr.2011.e39. eCollection 2011

6. Haque M, Hou JS, Hisamichi $K$, et al. Cutaneous and systemic plasmacytosis vs. cutaneous plasmacytic castleman disease: review and speculations about pathogenesis. Clin Lymphoma Myeloma Leuk. 2011;11(6):453461. doi: http://dx.doi.org/10.1016/j.clml.2011.07.004

7. Leonard AL, Meehan SA, Ramsey D, Brown L, Sen F. Cutaneous and systemic plasmacytosis. J Am Acad Dermatol. 2007; 56(2 Suppl):S38S40. doi: 10.1016/j.jaad.2006.05.019

8. Yashiro A ST, Shinamoto M. A kind of plasmacytosis: primary cutaneous plasmacytoma? Jpn J Dermatol. 1976;86(910).
9. Kitamura K, Tamura N, Hatano H, Toyama K, Mikata A, Watanabe S. A case of plasmacytosis with multiple peculiar eruptions. J Dermatol. 1980;7(5):341-9.

10. Chen $H$, Xue $Y$, Jiang $Y$, Zeng $X$, Sun JF. Cutaneous and systemic plasmacytosis showing histopathologic features as mixed-type Castleman disease: a case report. Am J Dermatopathol. 2012;34(5):5536. doi: 10.1097/DAD.0b013e3181f498e2

11. Miura H, Itami S, Yoshikawa K. Treatment of facial lesion of cutaneous plasmacytosis with tacrolimus ointment. Journal of the American Academy of Dermatology. 2003;49(6):1195-6. doi: http://dx.doi. org/10.1016/S0190-9622(03)00860-0

12. Tzung TY, Wu KH, Wu JC, Tseng HH. Primary cutaneous plasmacytosis successfully treated with topical photodynamic therapy. Acta Derm Venereol. 2005; 85(6):542-3. doi: 10.1080/00015550510027810

13. Yamamoto T, Soejima K, Katayama I, Nishioka K. Intralesional steroidtherapy-induced reduction of plasma interleukin- 6 and improvement of cutaneous plasmacytosis. Dermatology. 1995;190(3):242-4. doi: 10.1159/000246698

14. Uhara $\mathrm{H}$, Saida $\mathrm{T}$, Ikegawa $\mathrm{S}$, et al. Primary cutaneous plasmacytosis: report of three cases and review of the literature. Dermatology. 1994;189(3):2515. doi: 10.1159/000246848

15. Hafner $C$, Hohenleutner $U$, Babilas $P$, Landthaler $M$, Vogt $T$. Targeting $T$ cells to hit $B$ cells: successful treatment of cutaneous plasmacytosis with topical pimecrolimus. Dermatology. 2006;213(2):163-5. doi: 10.1159/000093860

16. Bower $\mathrm{M}$, Powles $\mathrm{T}$, Williams $\mathrm{S}$, et al. Brief communication: rituximab in HIV-associated multicentric Castleman disease. Ann Intern Med. 2007;147(12):836-9. doi:10.7326/0003-4819-147-12-200712180-00003

17. Mian $\mathrm{H}$, Leber $\mathrm{B}$. Mixed variant multicentric Castleman disease treated with rituximab: case report. J Pediatr Hematol Oncol. 2010;32(8):622. doi: 10.1097/MPH.0b013e3181f000e2

18. Hoffmann $C$, Schmid H, Muller M, et al. Improved outcome with rituximab in patients with HIV-associated multicentric Castleman disease. Blood. 2011;118(13):3499-3503. doi:10.1182/blood-2011-02-333633

19. Soumerai JD, Sohani AR, Abramson JS. Diagnosis and management of Castleman disease. Cancer Control. 2014;21(4):266-78.

20. Rhee FV, Casper C, Fayad LE, et al. An open-label, phase 2, multicenter study of the safety of long-term treatment with siltuximab (an antiinterleukin-6 monoclonal antibody) in patients with multicentric Castleman's disease. Blood. 2013;122(21):1806.

21. Nishimoto $N$, Kanakura $Y$, Aozasa $K$, et al. Humanized anti-interleukin- 6 receptor antibody treatment of multicentric Castleman disease. Blood. 2005;106(8):2627-32. doi: 10.1182/blood-2004-12-4602

22. Cheuk W, Chan JK. Lymphadenopathy of IgG4-related disease: an underdiagnosed and overdiagnosed entity. Semin Diagn Pathol. 2012;29(4):226-34. doi: 10.1053/j.semdp.2012.07.001

23. Ahmed B, Tschen JA, Cohen PR, et al. Cutaneous castleman's disease responds to anti interleukin- 6 treatment. Mol Cancer Ther 2007;6(9):2386-90. doi: 10.1158/1535-7163.MCT-07-0256

24. On HR, Lee $\mathrm{SE}$, Kim YC, Kim SC. Isolated benign primary cutaneous plasmacytosis in a child. Pediatr Dermatol. 2014;31(6):e120-121. doi: 10.1111/pde.12449

25. Ahn JJ, Yang YS, Shin MK, Lee SW, Kim NI. Case of isolated benign primary cutaneous plasmacytosis in a child. J Dermatol. 2011;38(4):3647. doi: $10.1111 / j .1346-8138.2010 .01111 . x$

26. Gilliam AC, Mullen RH, Oviedo $G$, et al. Isolated benign primary cutaneous plasmacytosis in children: two illustrative cases. Arch Dermatol. 2009;145(3):299-302. doi:10.1001/archdermatol.2008.596 